\title{
Ecological Inventory of Wetland Sites in the Thompson Chain of Lakes and Vicinity
}

\author{
Prepared for the \\ Montana Department of Fish, Wildlife, and Parks
}

Submitted by

Jack Greenlee and Marc Jones

November, 2000

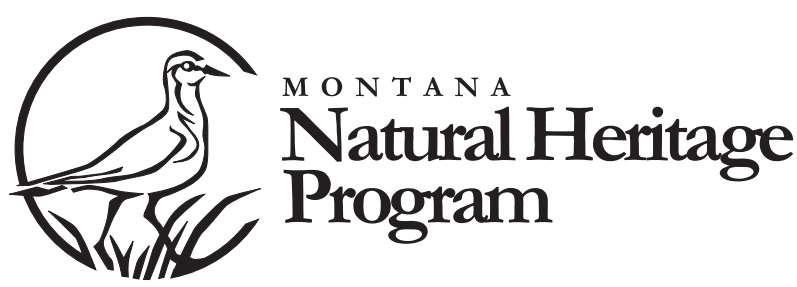




\section{Ecological Inventory of Wetland Sites in the Thompson Chain of Lakes and Vicinity}

November, 2000

(C) 2000 Montana Natural Heritage Program

State Library Building, P.O. Box 201800, Helena, MT 59620-1800. 406-444-3009

This document should be cited as follows:

Greenlee, J. and M. Jones. 2000. Ecological inventory of wetland sites in the Thompson Chain of Lakes and vicinity. Unpublished report to the Montana Department of Fish, Wildlife, and Parks. Montana Natural Heritage Program. Helena. 21 pp. 


\section{SUMMARY OF FINDINGS}

The Montana Natural Heritage Program surveyed seven wetland sites comprising 16 individual wetlands in the Thomspon Chain of Lakes and vicinity (Figure 1). Five of these sites are located in and around the Thompson Chain of Lakes (Figure 2), while the remaining two sites are located to the east along the Little Blackfoot River and around Rogers Lake (Figure 3). These sites were inventoried and evaluated using the methodology described in Greenlee (1999). Table 1 provides a summary of the criteria used to evaluate the ecological significance of these sites. All sites were surveyed in the summer of 1999.

The sites surveyed encompassed a diversity of wetland types, including poor fens, depressional potholes, spring/seeps, lacustrine fringe, and beaver-modified riverine wetlands. Structurally, emergent communities are the most common vegetation types with shrub-dominated communities well represented. Forested wetland communities were inventoried only at Rogers Lake and are represented by small stands of wet spruce and aspen.

We documented several occurrences of rare plants and animals. Three populations of rare plants were identified: slender cottongrass (Eriophorum gracile) and pod grass (Scheuchzeria palustris) were found at Crystal Lake and poor sedge (Carex paupercula) was found at Rogers Lake. Common loon (Gavia immer) and black tern (Chlidonias niger) were observed at Rogers Lake, and common loon was also observed at Upper Thompson. In addition, we documented several common wetland plant associations in excellent condition, including slender sedge (Carex lasiocarpa), beaked sedge (Carex utriculata), and Drummond willow / beaked sedge (Salix drummondiana / Carex utriculata).

\section{Ecological Significance}

Overall, the sites inventoried are of high to moderate ecological significance. Specifically, Rogers Lake, Crystal Lake, Upper Thompson, and Lily Pad Lake ranked as having high ecological significance, and Hidden Lake, Lower Thompson, and Boiling Springs ranked as having moderate ecological significance. Table 2 shows how sites were scored for each criterion as well as the overall score.

In evaluating these sites, two factors stand out as negatively influencing their functional integrity and long-term viability: past timber harvesting and the presence of exotic species. The surrounding uplands of all sites have been impacted by timber harvesting and associated roading. These activities may adversely effect the hydrology of these sites by increasing runoff, nutrient loading, and sedimentation. Most of the wetlands are buffered by Streamside Management Zones. These buffers have some overstory component remaining and may somewhat ameliorate adverse hydrological effects.

The second, and perhaps more troubling, adverse influence is the presence of exotic species, such as redtop (Agrostis stolonifera), Kentucky bluegrass (Poa pratensis), Canada thistle (Cirsium arvense), and reed canarygrass (Phalaris arundinacea). Exotic species are established at all sites except Hidden Lake. At most of the other sites, exotics are present with high constancy, but are restricted to drier locations, such as drawdown zones around potholes. The most advsersely effected site is Lower Thompson, where reed canarygrass is dominant throughout the site. The widespread presence and high constancy of exotic species at these sites is probably related to past grazing.

\section{LITERATURE CITED}

Greenlee, J.T. 1999. Ecologically significant wetlands in the Flathead, Stillwater, and Swan River valleys. Unpublished report to the Montana Department of Environmental Quality. Montana Natural Heritage Program. Helena. 192 pp. 
Figure 1. General location of wetland sites
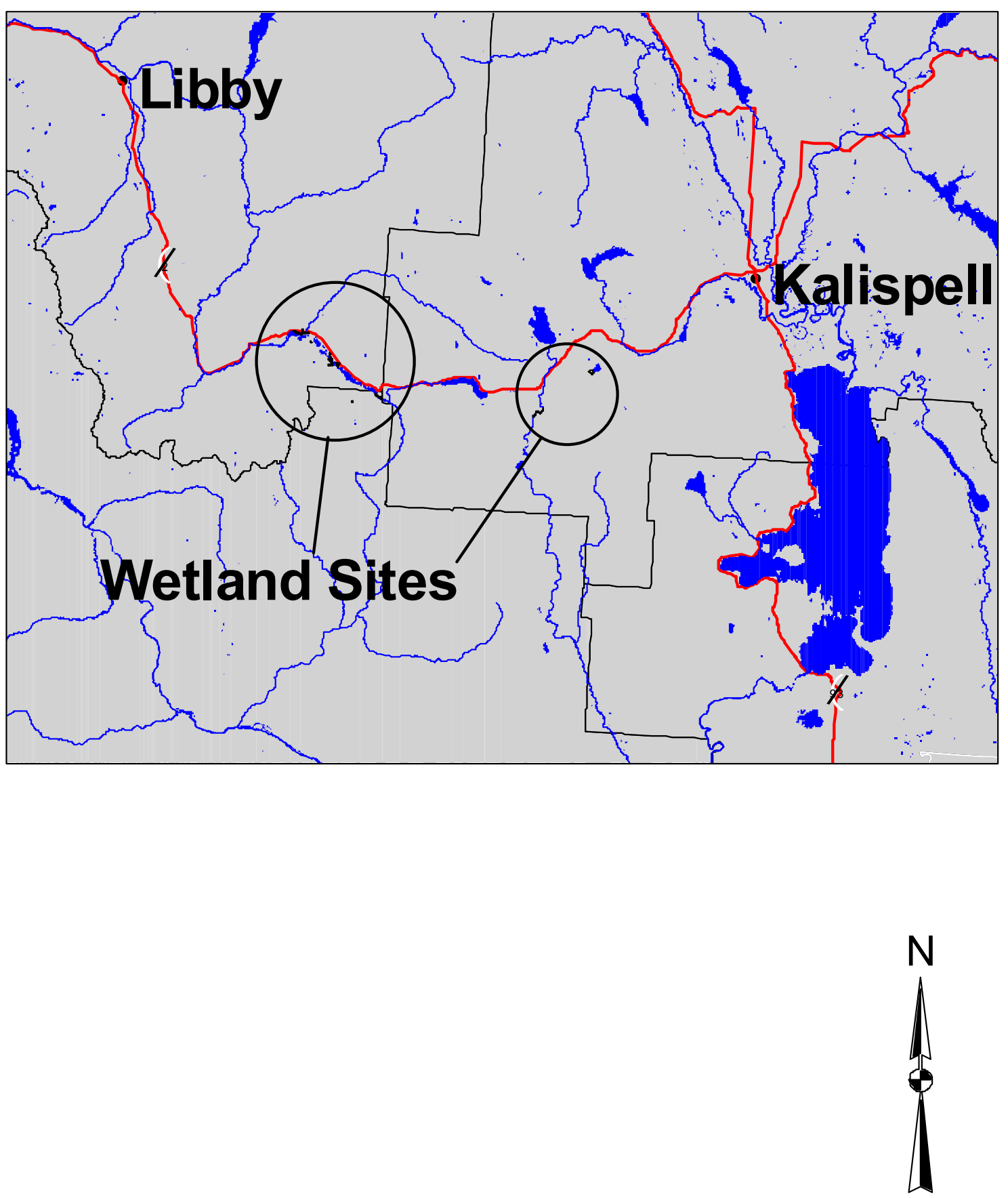
Figure 2. Thompson Chain of Lakes Sites (West)

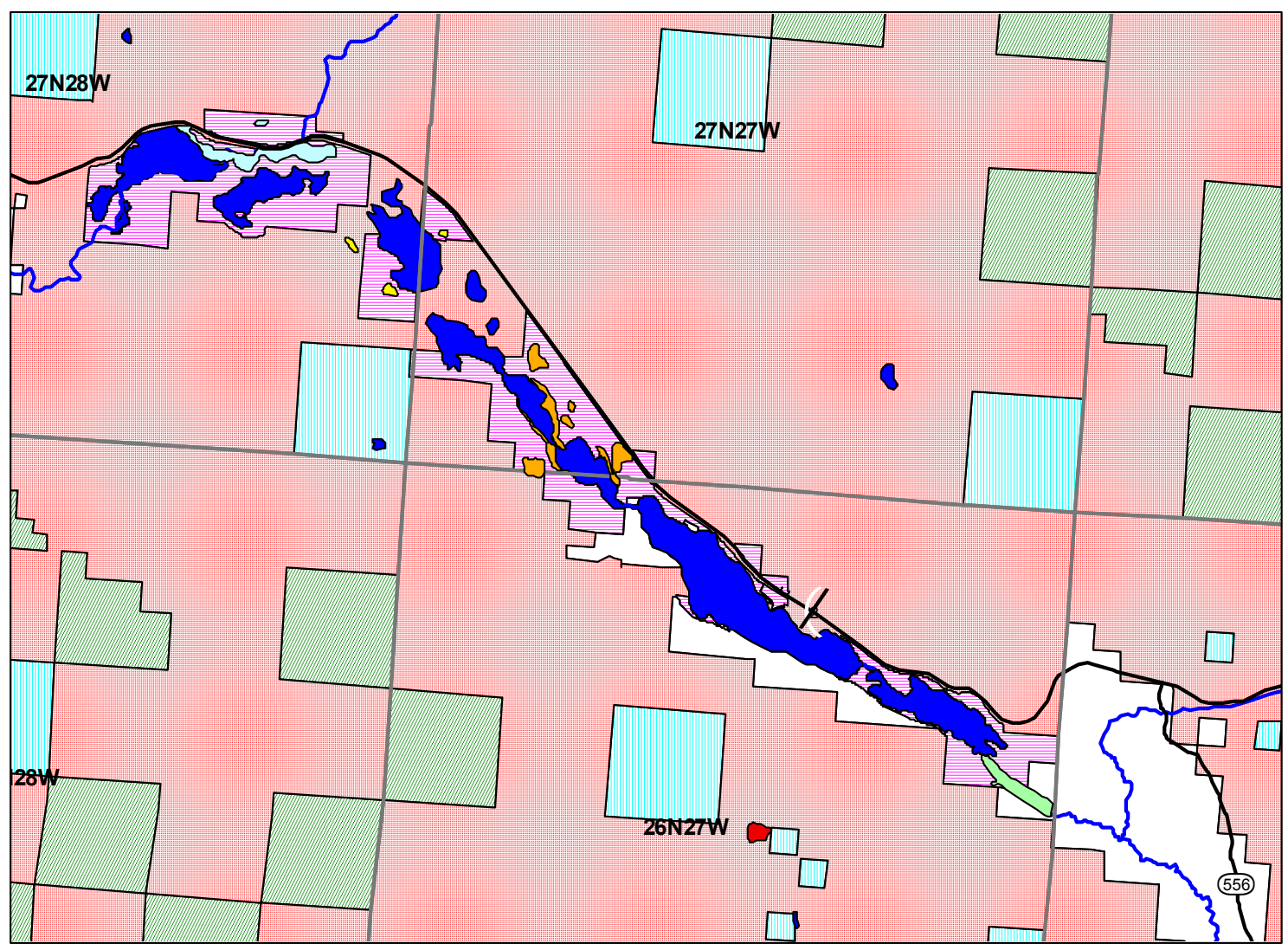

Wetland Sites

$\square$ Boiling Springs

Crystal Lake

Lily Pad Lake

Lower Thompson

Upper Thompson

Land Ownership Status

USFS

DNRC

FWP

Private, non corporate

PCTC

Lakes

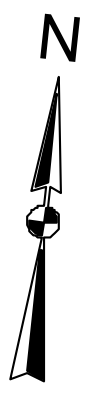


Figure 3. Thompson Chain of Lakes Sites (East)

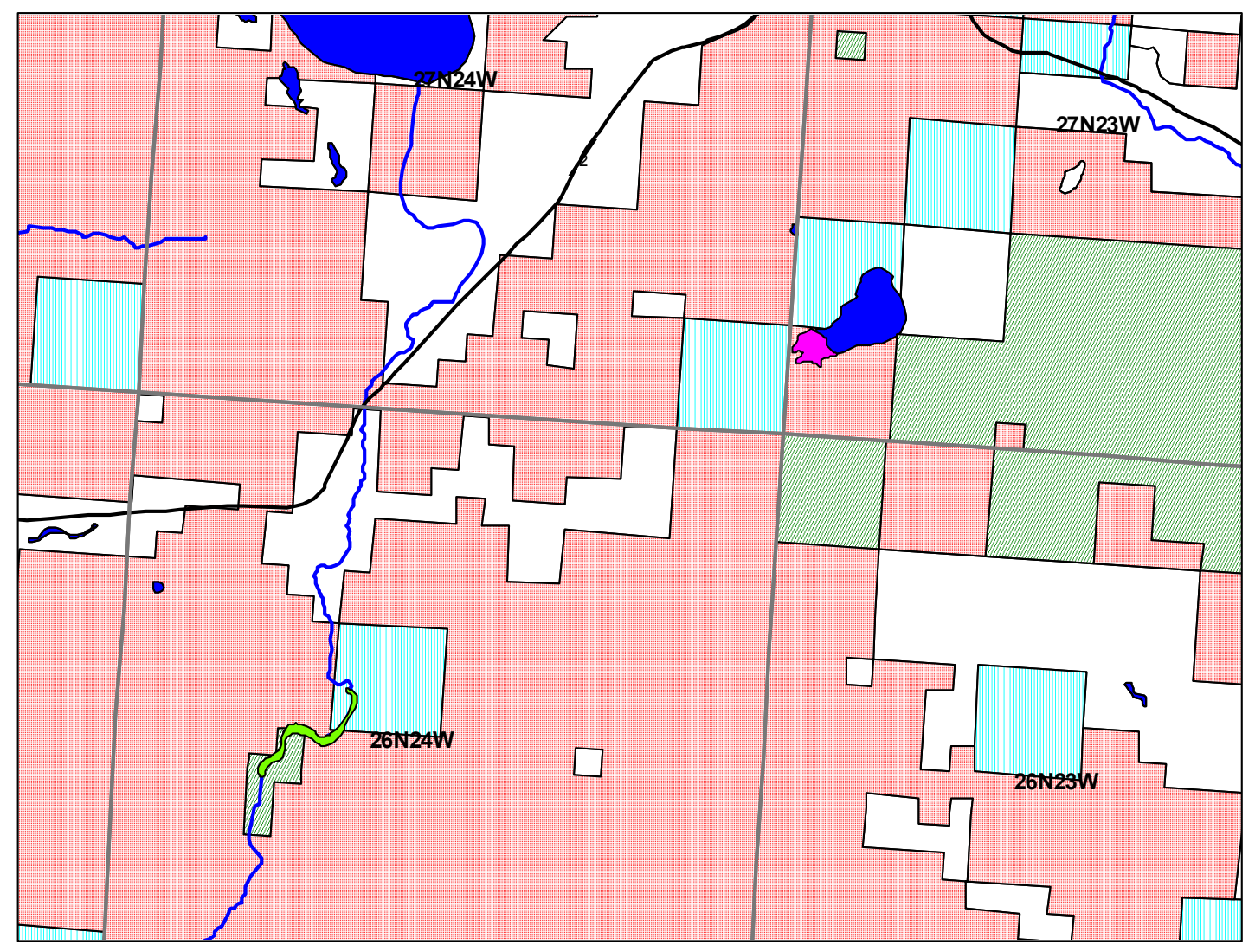

Wetland Sites

\begin{tabular}{|l}
$\square$ Hidden Lakes \\
\hline Rogers Lake
\end{tabular}

Rogers Lake

Land Ownership Status

USFS

DNRC

FWP

Private, non corporate

PCTC

Lakes

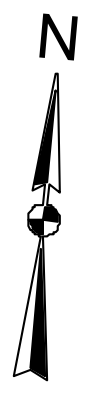


Table 1. Definitions and criteria for ranking a site's ecological significance.

\begin{tabular}{|c|c|c|c|c|}
\hline \multicolumn{2}{|c|}{$\begin{array}{l}\text { CRITERIA } \\
\text { Richness }\end{array}$} & DEFINITION & INDICATORS & RANKING SCORES \\
\hline & $\begin{array}{l}\text { Habitat diversity within } \\
\text { site }\end{array}$ & $\begin{array}{l}\text { - Assemblage of numerous } \\
\text { plant communities within } \\
\text { single unit of Cowardin's } \\
\text { classification } \\
\text { Assemblage of plant } \\
\text { communities or ecological } \\
\text { features (e.g., beaver } \\
\text { ponds, peatlands, lakes) } \\
\text { within several units of } \\
\text { Cowardin's classification } \\
\text { (= high structural } \\
\text { diversity) }\end{array}$ & $\begin{array}{l}\text { 3. Site has high diversity of vegetation types or wetland features. } \\
\text { 2. Site has a moderate diversity of vegetation types or wetland } \\
\text { features. } \\
\text { 1. Site has low diversity of ve getation types or wetland fe atures. }\end{array}$ \\
\hline \multicolumn{2}{|c|}{ Rarity } & $\begin{array}{l}\text { Presence of state rare } \\
\text { plant community, plant } \\
\text { or animal species, and } \\
\text { degree of rarity }\end{array}$ & $\begin{array}{l}\text { - High concentration of } \\
\text { state rare plant or animal } \\
\text { species } \\
\text { - Presence of globally rare } \\
\text { species or communities }\end{array}$ & $\begin{array}{l}\text { 3. Site has high concentration of rare species or communities. } \\
\text { 2. Site has moderate concentration of rare species or communities. } \\
\text { 1. Site has low concentration of rare species or communities } \\
\text { 0. Site has no rare species or communities }\end{array}$ \\
\hline \multirow{3}{*}{ 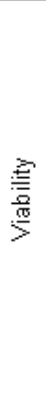 } & Condition & $\begin{array}{l}\text { Extent to which site } \\
\text { conditions (e.g. } \\
\text { processes, } \\
\text { communities) depart } \\
\text { from range of natural } \\
\text { variation }\end{array}$ & $\begin{array}{l}\text { Presence of on-site impacts } \\
\text { (e.g., exotics, grazing, roads, } \\
\text { ditching, irrigation withdrawal, } \\
\text { recreational use, timber } \\
\text { harvest) }\end{array}$ & $\begin{array}{l}\text { 3. Site in excellent condition; human impacts absent or minimal. } \\
\text { 2. Site in good condition; some impacts apparent. } \\
\text { 1. Site in poor condition; many impacts present. }\end{array}$ \\
\hline & Size & Areal extent of wetland & Acreage & $\begin{array}{l}\text { 3. Site is large ( }>40 \text { acres). } \\
\text { 2. Site is moderately large }(20-40 \text { acres) } \\
\text { 1. Site is small ( } 5-20 \text { acres) } \\
\text { 0. Site is very small ( }<5 \text { acres) }\end{array}$ \\
\hline & Uplands & $\begin{array}{l}\text { Landuse in surrounding } \\
\text { uplands }\end{array}$ & $\begin{array}{l}\text { Presence of off-site impacts } \\
\text { (e.g., timber harvest, roads, } \\
\text { homes, non-native } \\
\text { vegetation) }\end{array}$ & $\begin{array}{l}\text { 3. Site with minimal off-site impacts. } \\
\text { 2. Site with moderate level of off-site impacts. } \\
\text { 1. Site with high level of off-site impacts. }\end{array}$ \\
\hline
\end{tabular}

Table 2. Overview and rank of Thompson Chain of Lakes wetland sites

\begin{tabular}{|c|c|c|c|c|c|c|c|}
\hline Site & 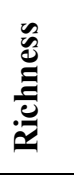 & 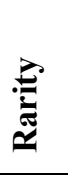 & ن & $\stackrel{\mathscr{n}}{\text { ñ }}$ & 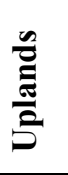 & 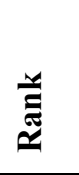 & Comments \\
\hline Rogers Lake & 2.5 & 1.5 & 2 & $3(51 \mathrm{ac})$ & 1.5 & 10.5 & $\begin{array}{l}\text { Diverse assemblage of communities, large, some communities } \\
\text { grazed, uplands heavily logged and grazed around wetland, potential } \\
\text { for subdivision, } 1 \text { rare plant, loons, black tern }\end{array}$ \\
\hline Crystal Lake & 2 & 1.5 & 3 & $1(12 \mathrm{ac})$ & 2 & 9.5 & $\begin{array}{l}\text { poor fen and potholes, } 2 \text { rare plants, timber harvest in uplands near } \\
\text { potholes }\end{array}$ \\
\hline Upper Thompson & 1.5 & 1 & 2 & $3(110 \mathrm{ac})$ & 2 & 9.5 & $\begin{array}{l}\text { exotics have invaded a number of communities, timber harvest to the } \\
\text { edge of all wetlands, past grazing, loons }\end{array}$ \\
\hline Lily Pad Lake & 2 & 0 & 3 & $3(96 \mathrm{ac})$ & 1.5 & 9.5 & $\begin{array}{l}\text { aquatic, emergent, shrub, and beaver activity; wetlands in good } \\
\text { condition, but with road forming border of one, timber harvest } \\
\text { around potholes }\end{array}$ \\
\hline Hidden Lakes & 1 & 0 & 3 & $3(58 \mathrm{ac})$ & 2 & 9 & $\begin{array}{l}\text { good condition beaver/willow complex, some logging in adjacent } \\
\text { uplands }\end{array}$ \\
\hline Lower Thompson & 2 & 0 & 1.5 & $3(57 \mathrm{ac})$ & 2 & 8.5 & $\begin{array}{l}\text { large, moderately diverse with emergent, shrub \& beaver activity, } \\
\text { lots of Phalaris arundinacea, uplands with timber harvest and } \\
\text { dispersed campsites }\end{array}$ \\
\hline Boiling Springs & 2 & 0 & 2 & $1(17 \mathrm{ac})$ & 2 & 7 & $\begin{array}{l}\text { large springs contribute to uniqueness of site, grazing has degraded } \\
\text { some of the sedge community, logging/road building has taken place } \\
\text { adjacent to site }\end{array}$ \\
\hline
\end{tabular}




\section{BOILING SPRINGS}

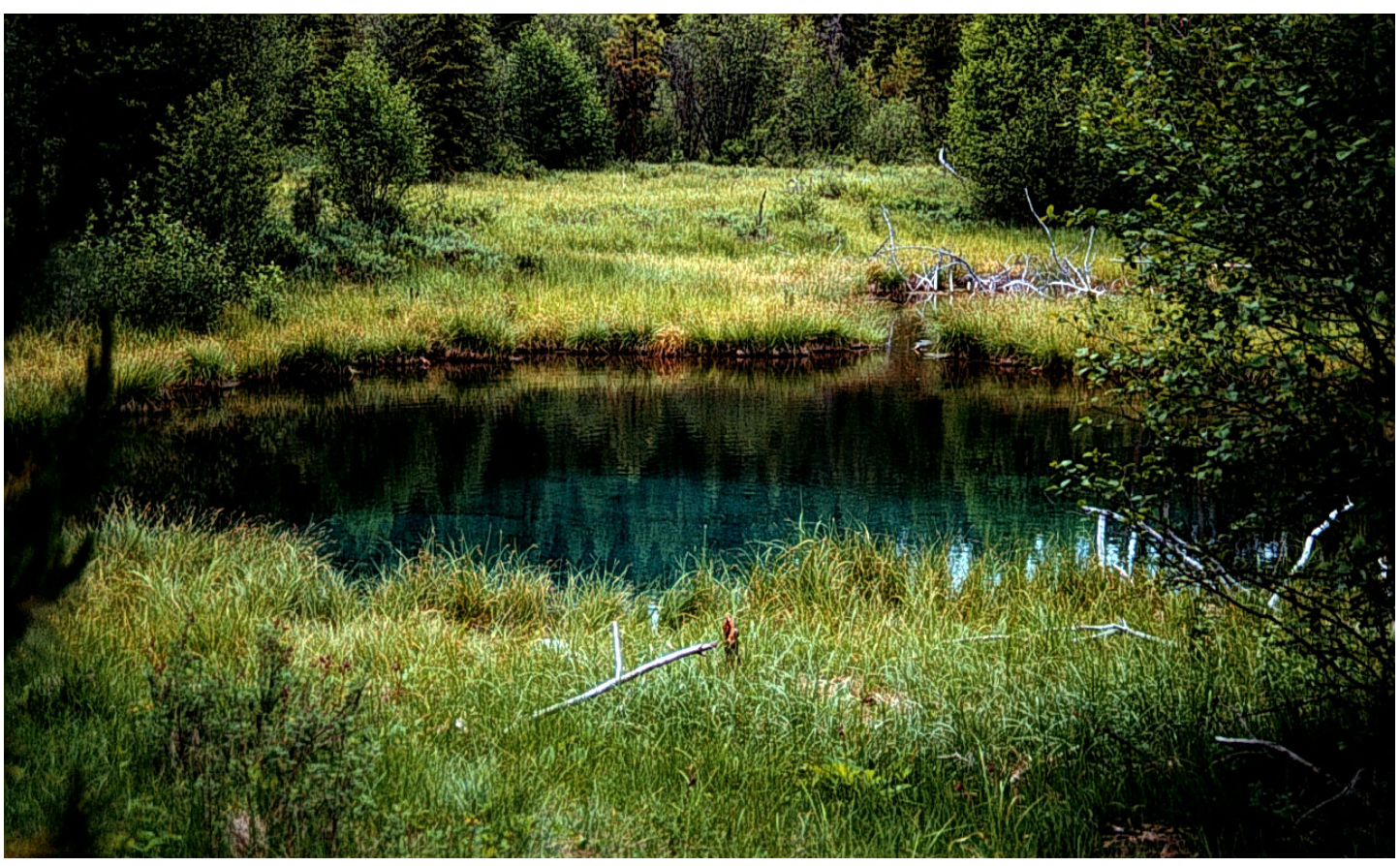

\section{Location}

The Boiling Springs site is located near the Thompson Chain of Lakes in the Salish Mountains of northwest Montana. From Kalispell travel approximately 60 miles west on U.S. Highway 2. Turn south on Lang Creek Cutoff Road. After 1.5 miles, turn southwest onto Boiling Springs Creek Road. Travel approximately 1.75 miles; the springs are adjacent to the road.

\section{Description}

This gently-sloping marsh and shrub-dominated wetland occurs at the toe of a slope in a narrow valley bottom. The water source is groundwater that intercepts an impermeable layer and wells up to the surface as seeps and springs. The two largest springs are 2-3 $\mathrm{m}$ in diameter and probably $2 \mathrm{~m}$ deep. Upwelling on the bottom of these pools disturbs sediments and is visible through the clear water. Other spring outlets appear to be overgrown by sedges and are discernible as small, deep openings surrounded by floating sedge mats. The water drains by surface and groundwater flow into an adjacent creek. The spring water is alkaline $(\mathrm{pH}=8.03-8.55)$ and has low levels of dissolved solutes (conductivity $=190-200 \mathrm{uS} / \mathrm{cm}$ ).

Two shrub communities occur above the main springs: a small Alnus incana (thin-leaved alder) community and a Betula glandulosa / Carex utriculata (bog birch / beaked sedge) community that is fed by numerous seeps. The Alnus incana community grades into a Carex cusickii (Cusick sedge) community immediately around the springs themselves. This community also occurs around some of the other smaller overgrown spring outlets. A Carex utriculata (beaked sedge) community occurs on the gentle slope between the springs and the creek. There are small upland "islands" scattered through the Carex utriculata community which are dominated by Pinus contorta (lodgepole pine), Picea engelmannii (Engelmann spruce), and Pseudotsuga menziesii (Douglas-fir). Dominance shifts from Carex utriculata to Poa pratensis (Kentucky bluegrass) in spots near these islands. No soil cores were taken, but this site appears to be more marsh than peatland, probably due to an ample flow of well-aerated groundwater.

\section{Key Environmental Factors}

An impermeable clay layer intercepts groundwater and causes the extensive seeps at this site. The resulting high groundwater table maintains these wetland communities. 


\section{Rarity}

No occurrences of any special status plant or animal species were observed. One small occurrence of a G3 community, Alnus incana / Carex (aquatilis, deweyana, lenticularis, lanuginosa, luzulina) Shrubland, was documented in excellent condition. Also, an undescribed Carex cusickii-dominated community was observed.

\section{Other Values}

Rana pretiosa (spotted frog) was observed around the largest springs.

\section{Landuse}

This site has probably been grazed in the past, as evidenced by old cowpies and the presence of Poa pratensis (Kentucky bluegrass) in drier portions of the site. However, the site does not appear to be currently grazed. The site appears to get little use.

\section{Exotics}

Poa pratensis (Kentucky bluegrass) and Rumex sp. are scattered in drier portions of the site. Cirsium arvense (Canada thistle) is rare but present throughout the site.

\section{Uplands}

The uplands have been logged in the past.

\section{Information Needs}

More information on landuse, especially grazing history. What is the source of water for the springs?

\section{Management Needs}

A road that runs around the uphill side of the site drains into the creek immediately below the site and is probably a major source of sediment.

\section{Element Occurrence Information}

\begin{tabular}{|c|c|c|c|}
\hline Plant Association / Community Type & EO Rank & S Rank & G Rank \\
\hline $\begin{array}{l}\text { Alnus incana / Carex (aquatilis, deweyana, lenticularis, lanuginosa, luzulina) } \\
\text { Shrubland }\end{array}$ & $\mathrm{C}$ & S? & G3 \\
\hline Betula glandulosa / Carex utriculata Shrubland & B & S4 & G4? \\
\hline Carex cusickii Dominance Type & * & $*$ & * \\
\hline Carex utriculata Herbaceous Vegetation & A & S5 & G5 \\
\hline
\end{tabular}

* rank not assigned 


\section{Crystal Lake}

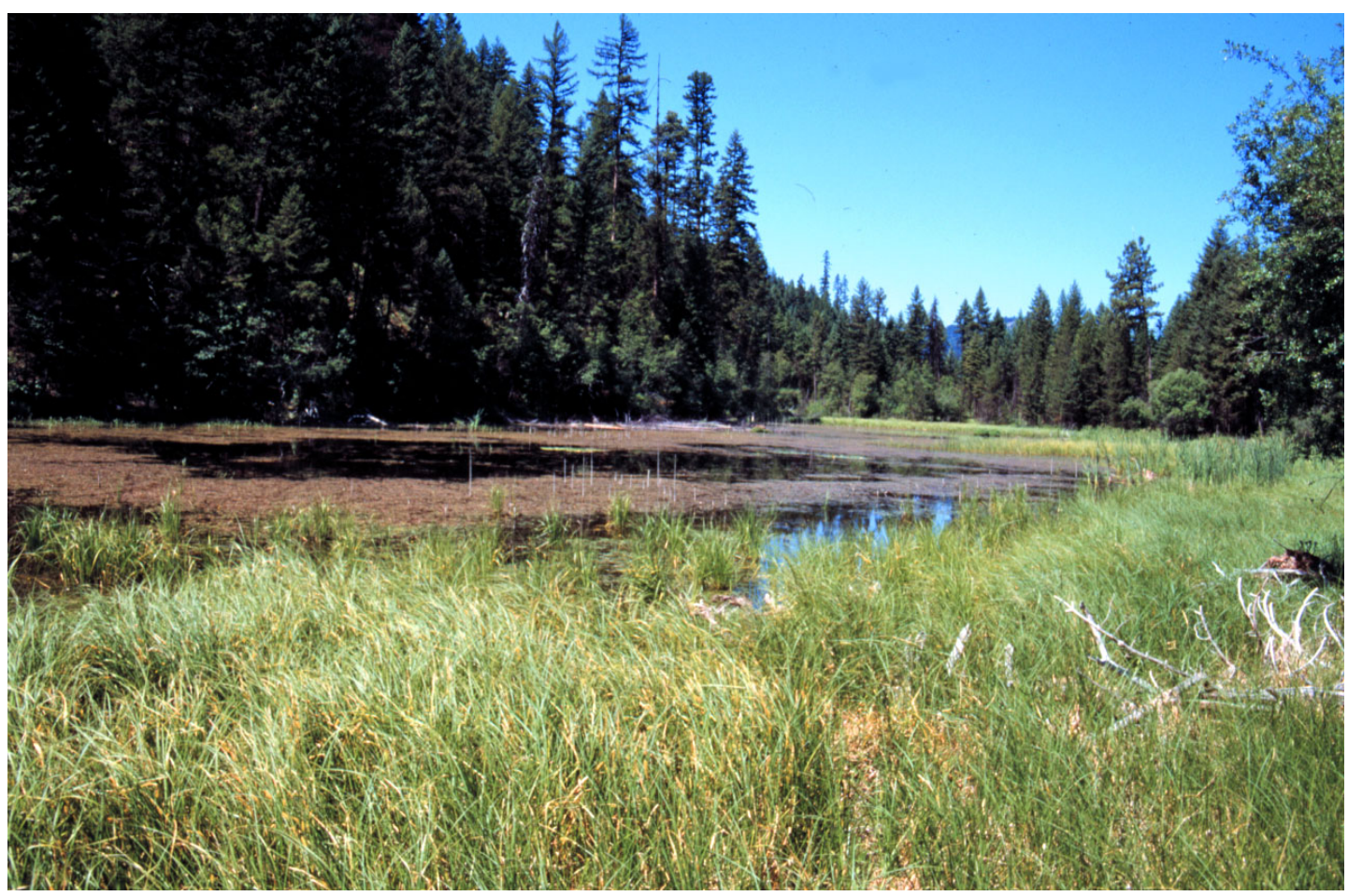

\section{Location}

These wetlands are part of the Thompson Chain of Lakes, which lie in the Salish Mountains of northwest Montana. From Kalispell, travel approximately 60 miles west on U.S. Highway 2. These wetlands are all within 0.5 mile of Crystal Lake, which lies near Happy's Inn, and can be reached via the system of logging roads built through the area.

\section{Description}

This site consists of three glacially-formed potholes occurring in a ground moraine that forms the drainage divide between the Thompson River and Pleasant Valley Fisher River watersheds. These wetlands are all topographically closed with no surface inlets or outlets. However, they are likely to have groundwater connections with nearby Crystal Lake. The conductivity of all three wetlands was low $(50-140 \mathrm{uS} / \mathrm{cm})$.

Two of the potholes (T27N R27W S19 SW1/4, T27N R28W S25 NW1/4) are compositionally and structurally similar. They occur in steep sided catchments and are dominated by aquatic communities. These aquatic communities are composed of a variety of floating-leaved and submerged plants such as Potamogeton natans (floating-leaved pondweed), Potamogeton gramineus (grass-leaved pondweed), Nuphar lutea (yellow water lily), Utricularia vulgaris (common bladderwort), and Sparganium sp. (bur-reed). The margins of each pothole are composed of a community that dries out seasonally as the water level draws down in late summer. Total plant cover is low in this zone, with Agrostis stolonifera (redtop) the dominant species. Other common forbs are Mentha arvensis (field mint), Ranunculus pennsylvanicus (Pennsylvania buttercup), Galium trifidum (small bedstraw), Potentilla norvegica (Norway cinquefoil), Argentina anserina (common silverweed), and Cirsium arvense (Canada thistle). The $\mathrm{pH}$ of the open water measured during the site visit was 6.9 to 7.8. The bottom of each pond is soft and muck-covered.

The remaining pothole is geomorphologically similar, but it is a poor fen rather than a shallow pond. It is not clear why significant peat accumulation has occurred in this depression and not the others, but perhaps there is more consistent groundwater seepage in this pothole. This would create permanently saturated conditions that in turn would lead to peat development. In any case, the wetland is dominated by a floating Carex limosa (mud sedge) community, which also has Carex interior (inland sedge), Carex diandra (lesser panicled sedge), Menyanthes trifoliata (bog buckbean), and high moss cover. An undescribed Comarum palustre (marsh cinquefoil) community 
rings this floating mat. This community was dried down to peaty muck near the edge of the pothole, but had about $30 \mathrm{~cm}$ of water near the edge of the floating mat. The $\mathrm{pH}$ of the water in this pothole was 5.8 , the most acidic of any measured in the Chain of Lakes area.

\section{Key Environmental Factors}

Seasonal flooding is the primary factor influencing vegetation patterns at this site.

\section{Rarity}

Eriophorum gracile (slender cottongrass, S2 / G4) and Scheuchzeria palustris (pod grass, S2 / G4) were documented in the poor fen. A moderately-sized occurrence of a G3 community, Carex limosa (mud sedge) Herbaceous Vegetation, was observed in excellent condition. There is also an undescribed Comarum palustre (marsh cinquefoil) community present. Both these communities occurred in the poor fen.

\section{Other Values}

Chrysemys picta (painted turtle) and Ondatra zibethicus (muskrat) were observed.

\section{Landuse}

Much of the area was historically grazed. Some sites probably receive some hunting and fishing use, but all appear relatively undisturbed.

\section{Exotics}

The drawdown zone around many of the depressions have a high constancy of exotics, including Agrostis stolonifera (redtop), Cirsium vulgare (bull thistle), Cirsium arvense (Canada thistle), and Potentilla norvegica (Norway cinquefoil).

\section{Uplands}

Nearly all surrounding uplands have been logged, although Stream Management Zones were generally observed with some overstory component remaining.

\section{Information Needs}

How much grazing occurred in this area in the past - this could explain high constancy of exotics (as could logging followed by deer dispersal). Are aquatic community-dominated lakes fed by groundwater? Historic aerial photographs from dry years could shed light on this.

\section{Management Needs}

Current and increased recreational use could create impacts to wetlands. Greater enforcement of existing regulations is needed (e.g., no felling of snags or disturbing loons).

\section{Element Occurrence Information}

\begin{tabular}{lccc}
\hline Plant Association / Community Type & EO Rank & S Rank & G Rank \\
\hline Agrostis stolonifera Herbaceous Vegetation & $*$ & $\mathrm{~S} 5$ & $\mathrm{GM}$ \\
Aquatic & $*$ & $*$ & $*$ \\
Carex limosa Herbaceous Vegetation & $\mathrm{B}$ & $\mathrm{S} 3$ & $\mathrm{G} 3$ \\
Carex utriculata Herbaceous Vegetation & $\mathrm{B}$ & $\mathrm{S} 5$ & $\mathrm{G} 5$ \\
Comarum palustris Herbaceous Vegetation & $*$ & $*$ & $*$ \\
Typha latifolia Western Herbaceous Vegetation & $\mathrm{B}$ & $\mathrm{S} 5$ & $\mathrm{G} 5$ \\
& & & \\
\hline Vascular / Nonvascular Plant Elements & $*$ & $\mathrm{~S} 2$ & $\mathrm{G} 4$ \\
\hline Eriophorum gracile (slender cottongrass) & $*$ & $\mathrm{~S} 2$ & $\mathrm{G} 4$ \\
Scheuchzeria palustris (pod grass) & & & \\
\hline
\end{tabular}

* rank not assigned 


\section{HidDEN LAKES}

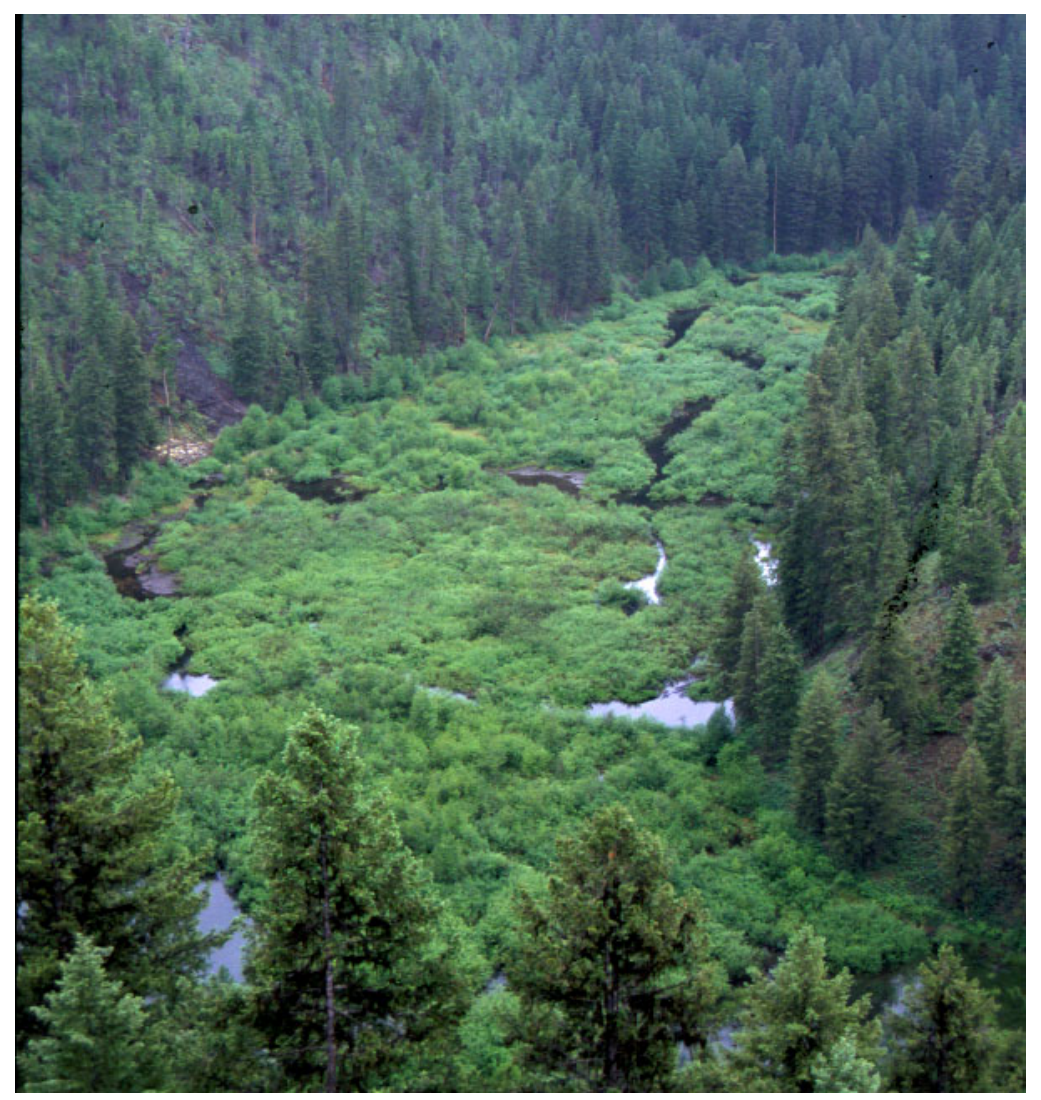

\section{Location}

Hidden Lakes is located in the Salish Mountains of northwestern Montana. From Kalispell, travel 30 miles west on U.S. Highway 2. Turn south and travel 4 miles on an unnamed logging road. Park at the top of a canyon overlooking Hidden Lakes.

\section{Description}

This series of lakes occurs in a deep, narrow canyon on the Little Bitterroot River. Beaver activity at the upper end of the first lake has resulted in a large Salix drummondiana / Carex utriculata (Drummond's willow / beaked sedge) complex. The willows occur on sediment deposits and numerous old beaver dams and intermingle with small openwater channels. There are some openings in the willow community that are covered by a Carex utriculata community. An Equisetum fluviatile (water horsetail) community occurs at the head of the first lake below the willow community. The lakes are long and narrow with little emergent or aquatic vegetation. The surrounding uplands are a Pseudotsuga menziesii (Douglas-fir)-dominated forest, some of which has been selectively logged recently.

\section{Key Environmental Factors}

Castor canadensis (beaver) activity is a primary influence in structuring and forming the willow community. Beaver dams and the willow community is very important in sediment retention at this site.

\section{Rarity}

No special status plant or animal species or globally rare plant communities were observed.

\section{Other Values}

Rana pretiosa (spotted frog) was observed at the site. 


\section{Landuse}

Current landuse appears to be limited to some fishing use in Hidden Lakes.

\section{Exotics}

No exotics were observed in the wetland. This site is isolated and wet.

\section{Uplands}

There is a dam on Little Bitterroot Lake, which affects water levels in the wetland. There has been logging in the uplands on both sides of the Little Blackfoot River (owned by Plum Creek Timber Company).

\section{Information Needs}

What is the extent of variation of flows in the Little Blackfoot River? Are there irrigation withdrawals?

\section{Management Needs}

\section{Element Occurrence Information}

\begin{tabular}{lccc}
\hline Plant Association / Community Type & EO Rank & S Rank & G Rank \\
\hline Carex utriculata Herbaceous Vegetation & A & S5 & G5 \\
Equisetum fluviatile Herbaceous Vegetation & A & S4 & G4 \\
Salix drummondiana / Carex utriculata Shrubland & A & S4 & G4 \\
\hline
\end{tabular}




\section{LiLY PAD LAKE}

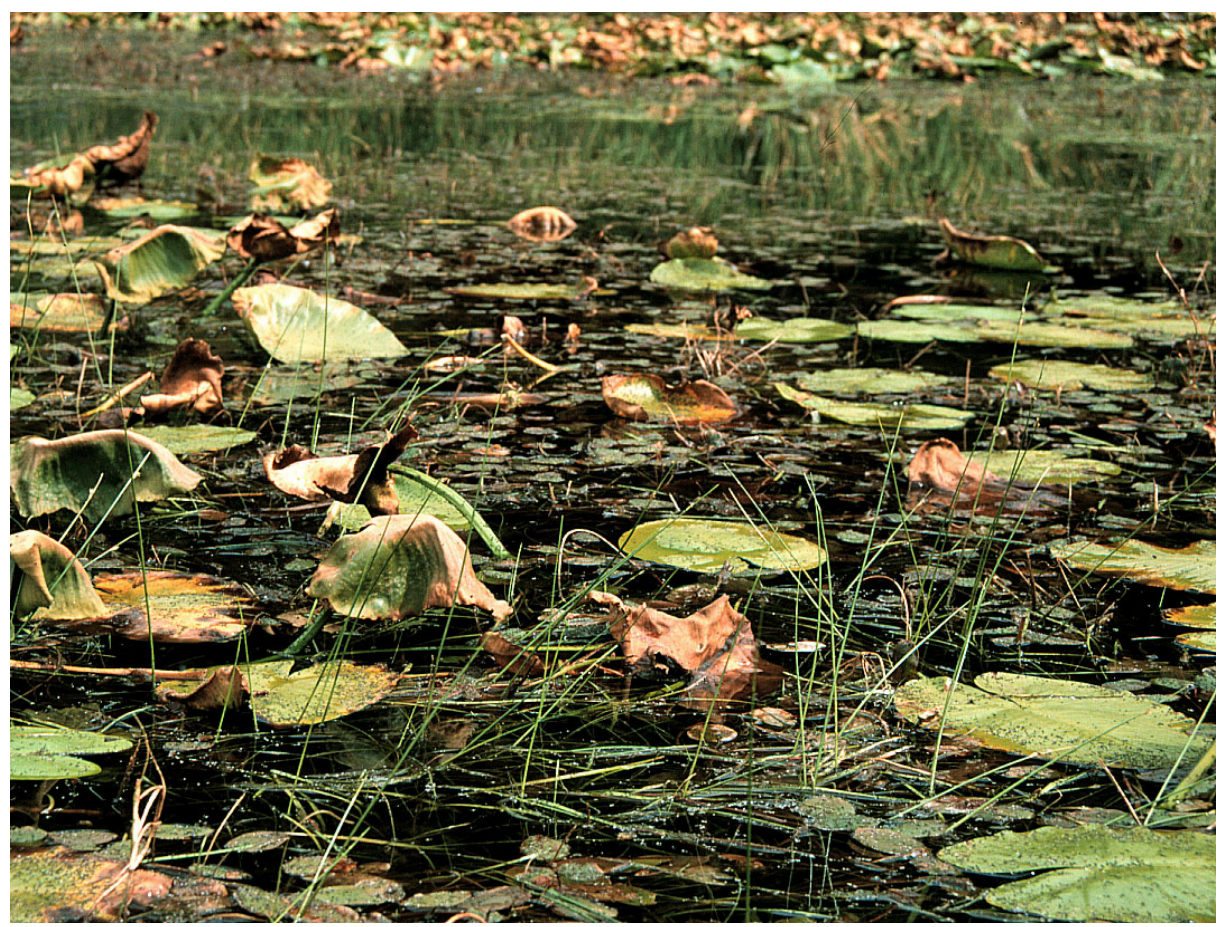

\section{Location}

These wetlands are part of the Thompson Chain of Lakes, which lie in the Salish Mountains of northwest Montana. From Kalispell, travel approximately 60 miles west on U.S. Highway 2. The Lily Pad Lake wetlands are about 1 mile west of Happy's Inn on Highway 2, where the Pleasant Valley Fisher River crosses the highway.

\section{Description}

This site is composed of two glacially-formed potholes that occur in a ground moraine in the Pleasant Valley Fisher River watershed and a willow bottom that occurs on this river just before it enters Loon Lake. One depression is topographically closed and probably connected by groundwater to the river. The other (Lily Pad Lake) is connected by surface water to the Pleasant Valley Fisher River. Beaver activity has played a large role in structuring the willow bottom. Water samples from these sites showed a $\mathrm{pH}$ range of 7.2-7.6, and a conductivity range of 80-170 $\mathrm{uS} / \mathrm{cm}$.

Both of the potholes are fairly steep sided, but one (T27N R28W S23 NW1/4 NE1/4) is relatively small and dominated by a Carex utriculata (beaked sedge) community with a fringe of Salix bebbiana (Bebb's willow) in the drawdown zone on the margins. The other, Lily Pad Lake, is a shallow lake with a deep muck bottom. This lake has a diverse aquatic plant community which is dominated by Potamogeton natans (floating-leaved pondweed), Sparganium minimum (small bur-reed), and Nuphar lutea ssp. variegatum (yellow water lily). There are also small patches of Scirpus acutus (hardstem bulrush), Typha latifolia (common cattail), and Carex utriculata around the lake. The willow bottom is a Salix drummondiana / Calamagrostis canadensis (Drummond's willow / bluejoint reedgrass) community. There are numerous beaver channels through this community.

\section{Key Environmental Factors}

Seasonal flooding is the primary factor influencing vegetation patterns at this site.

\section{Rarity}

No special status plant or animal species were observed. Two occurrences of G3 communities were observed: a very small example of Salix bebbiana (Bebb willow) Shrubland and a large occurrence of Salix drummondiana / Calamagrostis canadensis (Drummond willow / bluejoint reedgrass) Shrubland in very good condition. 


\section{Other Values}

A family of Mustela vison (mink) was observed at Lily Pad Lake (1 adult and 4 young).

\section{Landuse}

Much of the area was historically grazed. Some sites probably receive some hunting and fishing use, but all appear relatively undisturbed.

\section{Exotics}

The drawdown zone around many of the depressions have a high constancy of exotics, including Phalaris arundinacea (reed canarygrass), Cirsium arvense (Canada thistle), and Potentilla norvegica (Norway cinquefoil).

\section{Uplands}

Nearly all surrounding uplands have been logged, although Stream Management Zones were generally observed with some overstory component remaining. Highway 2 runs immediately adjacent to Lily Pad Lake and the willow bottom.

\section{Information Needs}

How much grazing occurred in this area in the past - this could explain high constancy of exotics (as could logging followed by deer dispersal). Are aquatic community-dominated lakes fed by groundwater? Historic aerial photographs from dry years could shed light on this.

\section{Management Needs}

Current and increased recreational use could create impacts to wetlands. Greater enforcement of existing regulations is needed (e.g., no felling of snags or disturbing loons).

\section{Element Occurrence Information}

\begin{tabular}{|c|c|c|c|}
\hline Plant Association / Community Type & EO Rank & S Rank & G Rank \\
\hline Carex utriculata Herbaceous Vegetation & $\mathrm{A}$ & S5 & G5 \\
\hline Nuphar lutea ssp. variegatum Dominance Type & $*$ & $*$ & $*$ \\
\hline Salix bebbiana Shrubland & $\mathrm{C}$ & S3? & G3? \\
\hline Salix drummondiana / Calamagrostis canadensis Shrubland & A & $\mathrm{S} ?$ & G3 \\
\hline Scirpus acutus Herbaceous Vegetation & $\mathrm{C}$ & S5 & G5 \\
\hline Typha latifolia Western Herbaceous Vegetation & $\mathrm{B}$ & S5 & G5 \\
\hline
\end{tabular}

* rank not assigned 


\section{LOWER THOMPSON}

\section{Location}

Lower Thompson Lake is part of the Thompson Chain of Lakes and lies in the Salish Mountains of northwest Montana. From Kalispell, travel west on U.S. Highway 2 for approximately 60 miles. Turn south on Lang Creek Cutoff Road. After crossing the Thompson River, turn right and proceed approximately 0.75 mile. The surveyed wetlands are northeast of the road.

\section{Description}

This wetland occurs in the floodplain of the Thompson River immediately below the outflow of Lower Thompson Lake. The Thompson River is a low-gradient, meandering stream in this reach. Glaciation scoured out the valley in which the Thompson Chain of Lakes sit, and past and current beaver activity played a large role in the development of this marsh. Most of the plant communities at this site are flooded seasonally from run-off during early summer; however, Lower Thompson Lake maintains high water tables year round. Scirpus acutus (hardstem bulrush) communities occur in the deepest water at the edge of the slow-moving Thompson River. Carex lasiocarpa (slender sedge) floating mats form a 5-10 foot wide fringe adjacent to the Scirpus acutus communities in spots. Typha latifolia (common cattail) and Carex utriculata (beaked sedge) communities occupy large portions of the marsh, particularly behind old beaver dams. A community dominated by the exotic Phalaris arundinacea (reed canarygrass) occupies slightly drier locations than the previous communities, and it is the largest community present at this site. Although this community is dominated by Phalaris arundinacea, it also has a relatively large Carex utriculata and Carex diandra (lesser panicled sedge) component. This is somewhat unusual as Phalaris arundinacea usually forms monospecific stands. Perhaps hydrologic conditions are not optimal for Phalaris arundinacea at this site, thus creating this unusual stand. An Alnus incana (thin-leaved alder) community, codominated by Alnus incana and Betula occidentalis (water birch), occurs at the margins of the marsh, next to the upland. Cornus sericea (red-osier dogwood) and a large individual Salix bebbiana (Bebb willow) are also important overstory species. The herbaceous layer has about equal coverage of forb and graminoid species. Common species are Carex utriculata, Carex diandra, Comarum palustre (marsh cinquefoil), and Mentha arvensis (field mint). The exotic Phalaris arundinacea is also common.

\section{Key Environmental Factors}

The low-gradient valley as well as past and current beaver activity is primarily responsible for structuring these communities.

\section{Rarity}

No special status plant or animal species or globally rare communities were observed at this site.

\section{Other Values}

Rana pretiosa (spotted frog) was observed at this site.

\section{Landuse}

The site does not appear to receive much use, except for occasional fishing access. Drier portions of the site were historically grazed when Plum Creek Timber Company owned the area.

\section{Exotics}

Phalaris arundinacea (reed canarygrass) dominates the majority of the marsh. It is also present at low cover in an adjacent, drier Alnus incana (thin-leaved alder) community. Wetter sites have no exotic species present.

\section{Uplands}

Uplands have been logged in the past. Dispersed campsites are present around the edge of the wetland.

\section{Information Needs}

\section{Management Needs}

Phalaris arundinacea (reed canarygrass) should be monitored in the wetland to detect increases in cover. Similar monitoring would be useful in other Thompson Chain of Lakes wetland sites. 
Element Occurrence Information

\begin{tabular}{lccc}
\hline Plant Association / Community Type & EO Rank & S Rank & G Rank \\
\hline Alnus incana Shrubland & $\mathrm{B}$ & $\mathrm{S} 3$ & $\mathrm{G}$ ? \\
Carex lasiocarpa Herbaceous Vegetation & $\mathrm{B}$ & $\mathrm{S} 4$ & G4? \\
Carex utriculata Herbaceous Vegetation & $\mathrm{A}$ & $\mathrm{S} 5$ & G5 \\
Phalaris arundinacea Western Herbaceous Vegetation & $*$ & $\mathrm{~S} 4$ & G5 \\
Scirpus acutus Herbaceous Vegetation & $\mathrm{B}$ & $\mathrm{S} 5$ & G5 \\
Typha latifolia Western Herbaceous Vegetation & $\mathrm{A}$ & $\mathrm{S} 5$ & G5 \\
\hline
\end{tabular}

* rank not assigned 


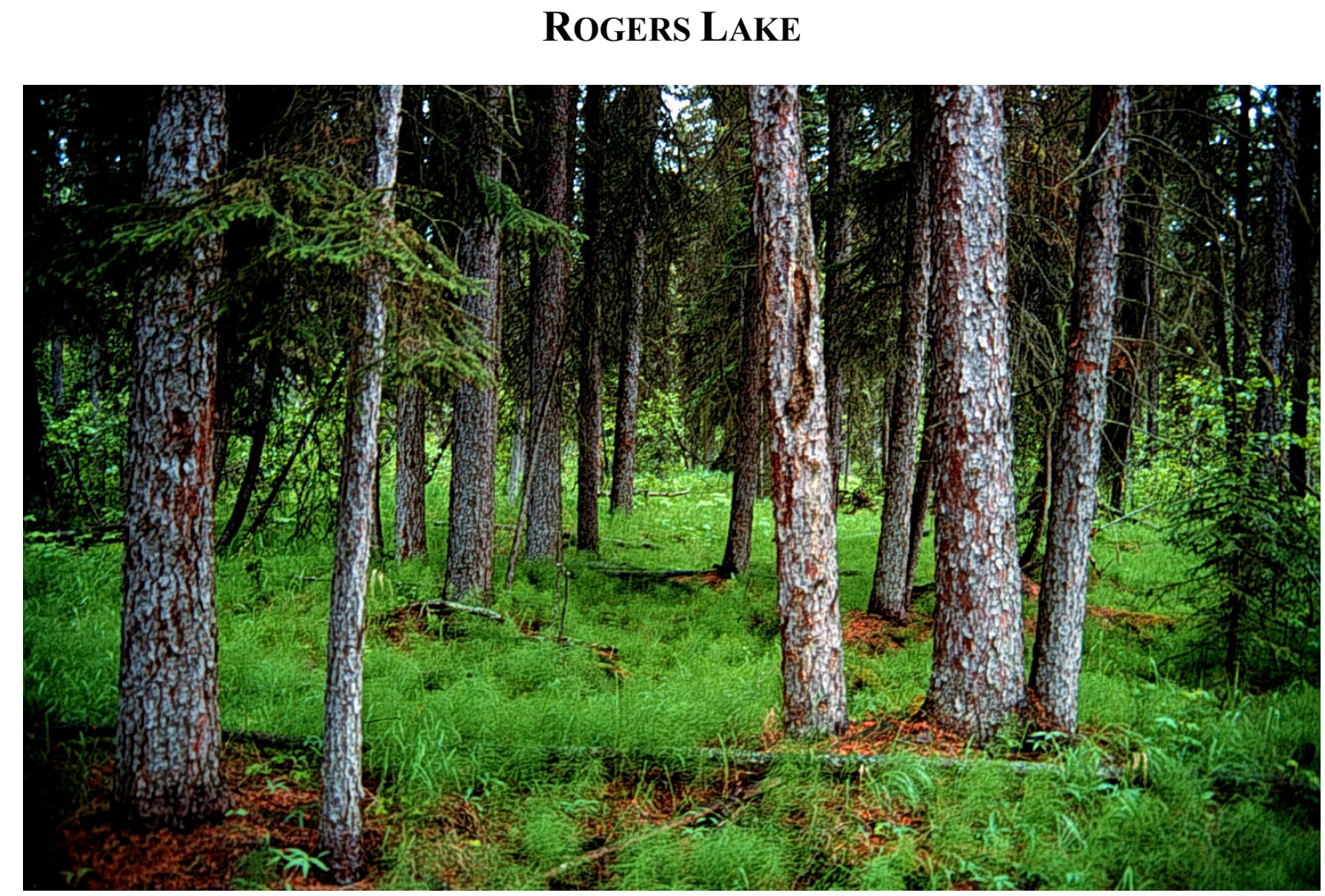

\section{Location}

Rogers Lake is located in the Salish Mountains of northwest Montana. From Kalispell, travel west on U.S. Highway 2 for approximately 18 miles. Turn south on Forest Route 914 . Travel for about 5 miles to Rogers Lake. Travel around the north side of the lake. The wetlands are located at the southwest end of the lake.

\section{Description}

Rogers Lake is a large, glacially-formed depression. Several small creeks flow into the basin, but at current lake levels there is no surface outlet. Water chemistry measurements indicate that $\mathrm{pH}$ is circumneutral $(\mathrm{pH}=7.5)$, and that there are low concentrations of dissolved solutes (conductivity $=90 \mathrm{uS} / \mathrm{cm}$ ).

The wetland at the southwest end of Rogers Lake is composed of a floating sedge mat surrounded by marsh vegetation. The large floating mat is a Carex lasiocarpa (slender sedge) community that rises and falls with the water level. Surrounding the mat is a Carex utriculata (beaked sedge) community that is anchored to the substrate; thus water depths are much greater in this community than in the former. Both are in excellent condition. There are some small patches of Typha latifolia (common cattail) in the marsh as well. On the margins of the marsh and in some of the small "fingers" of the wetland that project to the west, there are some small, moderately impacted Betula occidentalis (water birch) communities. On the south edge of the wetland, on part of the lakeplain where a creek enters, there is a wet spruce forest composed of Picea engelmannii / Calamagrostis canadensis (Engelmann spruce / bluejoint reedgrass) and Picea engelmannii / Equisetum arvense (Engelmann spruce / field horsetail) communities. These are in good condition. On the opposite side of the lake is a small Populus tremuloides / Poa pratensis (quaking aspen / Kentucky bluegrass) community that has been degraded by grazing. The surrounding uplands are Pseudotsuga menziesii / Calamagrostis rubescens (Douglas-fir / pinegrass) forest.

\section{Key Environmental Factors}

The three creeks at the southwest end of the lake contribute surface water and are probably important in structuring marsh community formation.

\section{Rarity}

An occurrence of Carex paupercula (poor sedge, S3 / G5), located in the Picea engelmannii / Equisetum arvense (Engelmann spruce / field horsetail) community, was documented at this site. Chlidonias niger (black tern, S3B, 
SZN / G4) and a pair of Gavia immer (common loon, S1S2B, SZN / G5) were observed at this site. This site also contains Betula occidentalis (water birch) communities of uncertain classification status.

\section{Other Values}

Rana pretiosa (spotted frog) was observed at this site.

\section{Landuse}

The northern portion of the site appears to have been grazed in the past along the wetland margin. Timber harvest has occurred along the southern portion of the site adjacent to the Picea engelmannii / Equisetum arvense (Engelmann spruce / field horsetail) community.

\section{Exotics}

The marsh is remarkably free of exotics, especially Phalaris arundinacea (reed canarygrass). Exotics are limited to the Populus tremuloides (quaking aspen) community. This formerly-grazed community is dominated by Poa pratensis (Kentucky bluegrass) in the groundlayer. Phleum pratense (common timothy), Cynoglossum officinale (hound's tongue), and Potentilla recta (sulphur cinquefoil) are also present at low cover.

\section{Uplands}

Timber harvest and grazing occur in the uplands. A streamside management zone buffers most of the wetland. Housing development is occurring around the lake with empty lots yet to be sold. Additional development may occur on the south side of the lake. Lake eutrophication is a possible consequence of this development.

\section{Information Needs}

Is the north edge of site currently grazed? A fence is present in the uplands near the aspen stand - does this fence exclude livestock from the lakeshore and marsh edge? How much of lake outflow is to groundwater.

\section{Management Needs}

Water quality monitoring is needed.

\section{Element Occurrence Information}

\begin{tabular}{|c|c|c|c|}
\hline Plant Association / Community Type & EO Rank & S Rank & G Rank \\
\hline Betula occidentalis / Carex utriculata Dominance Type & $\mathrm{C}$ & $*$ & $*$ \\
\hline Carex lasiocarpa Herbaceous Vegetation & A & $\mathrm{S} 4$ & G4? \\
\hline Carex utriculata Herbaceous Vegetation & A & S5 & G5 \\
\hline Picea engelmannii / Calamagrostis canadensis Forest & $\mathrm{B}$ & S4 & G4 \\
\hline Picea engelmannii / Equisetum arvense Forest & $\mathrm{B}$ & S4 & G4 \\
\hline Populus tremuloides / Poa pratensis Dominance Type & $*$ & $*$ & $*$ \\
\hline Typha latifolia Western Herbaceous Vegetation & A & S5 & G5 \\
\hline \multicolumn{4}{|l|}{ Animal Elements } \\
\hline Chlidonias niger (black tern) & $*$ & S3B, SZN & G4 \\
\hline Gavia immer (common loon) & $*$ & S1S2B, SZN & G5 \\
\hline \multicolumn{4}{|l|}{ Vascular / Nonvascular Plant Elements } \\
\hline Carex paupercula & $*$ & $\mathrm{~S} 3$ & G5 \\
\hline
\end{tabular}




\section{UPPER THOMPSON}

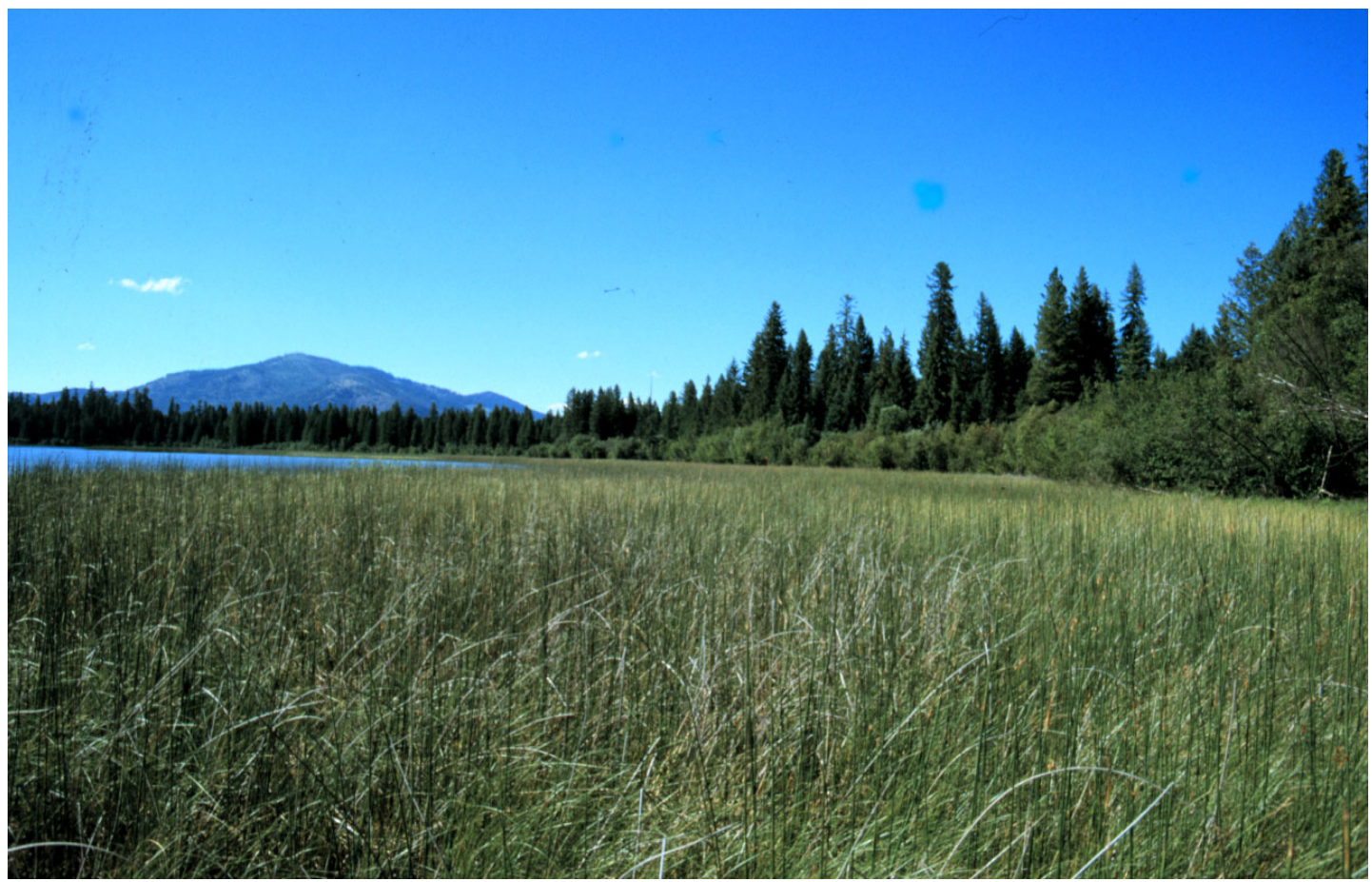

\section{Location}

These wetlands are part of the Thompson Chain of Lakes, which lie in the Salish Mountains of northwest Montana. From Kalispell, travel approximately 60 miles west on U.S. Highway 2 to Upper Thompson Lake. These wetlands are all within 0.25 mile of Upper Thompson Lake and can be reached via the system of logging roads built through the area.

\section{Description}

This small complex is composed of five potholes and the wetland fringe that occurs on the margins of Upper Thompson Lake. All are glacial in origin and occur at the headwaters of the Thompson River. Three of the potholes in this complex are topographically closed, with no inlet or outlet, and the other two potholes drain (at least periodically) into Upper Thompson Lake via a surface water connection. All are likely to have groundwater connections to nearby Upper Thompson Lake.

All of the potholes are similar compositionally and structurally. They occur in catchments that slope gradually down to the wetland, and are dominated by marsh vegetation. Either Typha latifolia (common cattail) or Scirpus acutus (hardstem bulrush) dominates the wettest zones. These communities occupy the majority of the acreage in all but one pothole, which is somewhat shallower and dominated by a Carex utriculata (beaked sedge) community. All these potholes have been invaded to some extent by Phalaris arundinacea (reed canarygrass), which primarily occurs on the drier margins of the wetlands. At two of the potholes, the Phalaris arundinacea community intergrades with two other exotic-dominated communities, Agrostis stolonifera (redtop) and Poa pratensis (Kentucky bluegrass).

Three communities dominate the margins of Upper Thompson Lake. Each community is zonally distributed along a topographic and moisture gradient. From driest to wettest, these communities are a shrub margin, a floating sedge mat, and a Scirpus acutus community. Most of the shrub margin is flooded intermittently and dominated by a Betula occidentalis (water birch) community, although in spots dominance shifts to Salix bebbiana (Bebb's willow). The shrub community grades into a Carex lasiocarpa (slender sedge) floating mat, which is well-anchored on the edge adjacent the shrub community, and floating nearer the open water. This community is saturated year-round by water from Upper Thompson Lake. Between the sedge mat and the open water is a 10-30 foot wide band of Scirpus 
acutus, which in turn grades into open water. This wetland vegetation occurs around approximately 30 percent of Upper Thompson Lake.

\section{Key Environmental Factors}

Seasonal flooding and fluctuations in lake level appear to be the primary influence on plant community structure.

\section{Rarity}

Gavia immer (common loon, S1S2B, SZN / G5) are known to nest in the vicinity. No special status plant species were observed; however, a G3 community, Betula occidentalis / Cornus sericea (water birch / red-osier dogwood), was documented in good condition.

\section{Other Values}

These sites provide wildlife habitat; birds observed include grebe and great blue heron. No amphibians were observed.

\section{Landuse}

Wet meadows around wetlands were historically grazed. Current recreational uses have resulted in some informal trail development. An ORV was driven partway into one of the depressional wetlands.

\section{Exotics}

Cirsium arvense (Canada thistle), Cynoglossum officinale (hound's tongue), Poa pratensis (Kentucky bluegrass), and Phalaris arundinacea (reed canarygrass) are present with high constancy. The presence of exotics is probably related to past grazing.

\section{Uplands}

The surrounding uplands are logged and roaded and now support many dispersed campsites. Campers have cut some snags for firewood. Highway 2 runs along the edge of one wetland (Eli Lake).

\section{Information Needs}

Do historic aerial photographs show amount of Typha latifolia (common cattail) around Eli Lake prior to construction of Highway 2? How much grazing occurred in this area in the past - this could explain high constancy of exotics (as could logging followed by deer dispersal). Are aquatic community-dominated lakes fed by groundwater? Historic aerial photographs from dry years could shed light on this.

\section{Management Needs}

Current and increased recreational use could create impacts to lacustrine fringe wetlands. Greater enforcement of existing regulations is needed (e.g., no felling of snags or disturbing loons).

\section{Element Occurrence Information}

\begin{tabular}{lccc}
\hline Plant Association / Community Type & EO Rank & S Rank & G Rank \\
\hline Agrostis stolonifera Herbaceous Vegetation & $*$ & $\mathrm{~S} 5$ & $\mathrm{GM}$ \\
Aquatic & $*$ & $*$ & $*$ \\
Betula occidentalis / Cornus stolonifera Shrubland & $\mathrm{B}$ & $\mathrm{SP}$ & $\mathrm{G} 3 ?$ \\
Calamagrostis canadensis Western Herbaceous Vegetation & $\mathrm{C}$ & $\mathrm{S} 4$ & $\mathrm{G} 4$ \\
Carex lasiocarpa Herbaceous Vegetation & $\mathrm{A}$ & $\mathrm{S} 4$ & $\mathrm{G} 4$ ? \\
Carex utriculata Herbaceous Vegetation & $\mathrm{A}$ & $\mathrm{S} 5$ & $\mathrm{G} 5$ \\
Juncus balticus Herbaceous Vegetation & $\mathrm{B}$ & $\mathrm{S} 5$ & $\mathrm{G} 5$ \\
Phalaris arundinacea Western Herbaceous Vegetation & $*$ & $\mathrm{~S} 4$ & $\mathrm{G} 5$ \\
Poa pratensis Semi-natural Seasonally Flooded Herbaceous Alliance & $*$ & $\mathrm{SW}$ & $\mathrm{GW}$ \\
Salix bebbiana Shrubland & $\mathrm{C}$ & $\mathrm{S} 3$ & $\mathrm{G} 3$ \\
Scirpus acutus Herbaceous Vegetation & $\mathrm{A}$ & $\mathrm{S} 5$ & $\mathrm{G} 5$ \\
Typha latifolia Herbaceous Vegetation & $\mathrm{A}$ & $\mathrm{S} 5$ & $\mathrm{G} 5$ \\
& & & \\
\hline Animal Elements & $*$ & S1S2B, SZN & G5 \\
\hline Gavia immer (common loon) & &
\end{tabular}

* rank not assigned 


\section{APPENDIX. Global AND State Rank GuidelineS}

For state ranks, substitute $\mathrm{S}$ for $\mathrm{G}$ in these definitions

G1 = Critically imperiled globally because of extreme rarity (typically five or fewer occurrences or very few remaining acres) or because of some factor(s) making it extremely vulnerable to exptirpation.

$\mathrm{G} 2=$ Imperiled globally because of extreme rarity (typically six to 20 occurrences or few remaining acres) or because of some factor(s) making it very vulnerable to extirpation.

$\mathrm{G} 3=$ Vulnerable; either very rare and local throughout its range or found locally (even abundantly at some of its locations) in a restricted range (e.g. a single Great Plains state, a single physiographic or ecoregional unit) or because of other factors making it vulnerable to extirpation throughout it's range.

$\mathrm{G} 4=$ Apparently Secure; Uncommon, but not rare (although it may be quite rare in parts of its range, especially at the periphery). Apparently not vulnerable in most of its range.

G5 = Secure; Common, widespread, and abundant (though it may be quite rare in parts of its range, especially at the periphery). Not vulnerable in most of its range.

$\mathrm{GU}=$ Unrankable; Status cannot be determined at this time.

$\mathrm{G} ?=$ Unranked; Status has not yet been assessed.

$\mathrm{GM} / \mathrm{GW}=$ Designates a community that is modified and dominated by cultivated or weedy species.

\section{$\underline{\text { Modifiers and Rank Ranges }}$}

? A question mark added to a rank expresses an uncertainty about the rank in the range of 1 either way on the 1-5 scale.

G\#G\# Greater uncertainty about a rank is expressed by indicating the full range of ranks which may be appropriate.

Q A "Q" added to a rank denotes questionable taxonomy. It modifies the degree of imperilment and is only used in cases where the type would have a less imperiled rank if it were not recognized as a valid name (i.e. if it were combined with a more common type).

P Assigned at the state level. There is potential that the element occurs in the state, but no extant or historic occurrences are accepted.

$\mathrm{R} \quad$ Assigned at the state level. Element is reported as occurring in the state but without a basis for either accepting or rejecting the report. 


\section{CRITERIA USED FOR RANKING}

The criteria for ranking are based on a set of quantitative and qualitative factors. These factors are listed below in order of their general importance:

a. Number of Element Occurrences (EOs):

the estimated number of EOs throughout the Element's global range;

b. Abundance:

the estimated global abundance of the Element (measured by number of individuals, or area, or stream length covered);

c. Size of Range:

the estimated size of the Element's global range;

d. Distribution trend:

the trend in the Element's distribution over it's global range;

e. Number of protected EOs:

the estimated number of adequately protected EOs throughout the Element's global range;

f. Degree of threat:

the degree to which the Element is threatened globally;

g. Fragility:

the fragility or susceptibility of the Element to intrusion;

h. Other global considerations:

for example, the quality or condition of EOs that affect or may affect endangerment status; unexplained population fluctuations; reproductive strategies that are dependent on specific habitat; etc. 